\title{
Parental Awareness and Attitudes of Digital Media Advertising to Children
}

\author{
Ljupka Naumovska $^{1}$, Dimitar Jovevski ${ }^{2}$ and Katarina Brockova ${ }^{3}$
}

${ }^{1}$ Assistant Professor, Faculty of Marketing, University of Tourism and Management, Skopje

${ }^{2}$ Associate professor, Faculty of Economics-Skopje, Ss. Cyril and Methodius University in Skopje, Macedonia

3 Associate Professor, Faculty of International Relations, University of Economics in Bratislava, Slovakia

\begin{tabular}{ll} 
ARTICLE INFO & ABSTRACT \\
\hline $\begin{array}{l}\text { Keywords: } \\
\text { Advertising } \\
\text { On line media } \\
\text { Children }\end{array}$ & $\begin{array}{l}\text { Children today are very comfortable using electronic technology, } \\
\text { Internet, on line games and digital platforms. The dominant portion } \\
\text { of the on line content is consumed via their parent's technological } \\
\text { Regulations }\end{array}$ \\
covices. Knowing that children are not able to recognize media \\
content from intentional advertising, raises the complex question of \\
whether and how Internet advertising can be regulated and how \\
children can be protected. The negative implications of children's \\
exposure to on line advertising can be categorized in: financial and \\
psychological, and are summarized but not limited to: obesity, \\
anxiety paired with influence over domestic spending's, \\
psychological and ethical issues. This raises the complex question of \\
whether and how Internet advertising can be regulated and how \\
children can be protected from the negative implications. The \\
majority of research are focused on institutional regulations and \\
industrial limitations but the importance and the role of the parents \\
as a regularity mechanism is underestimated. The theory recognizes \\
that certain parental style differs on how they view online exposure \\
of their children and that influence their role in the process on \\
regulation children exposure on online advertising. From the other \\
side digital literacy of the parents is very important milestone in the \\
proses positioning the parents in a role of as a self-regulation \\
mechanism of children exposure. The industry and the regulators \\
should be alerted for this matter in all parts of the world, since this \\
issue is rising negative implication.
\end{tabular}

\section{Introduction}

The key objective of this theoretical review is to provide an understanding of the new and dynamic marketing environment of online marketing that children (members of Generation Z) are directly or indirectly exposed to, in order to provide a basis for future research, policy recommendations, self-regulations and most importantly - increasing parental awareness as a new and direct instrument for regulations and decrease of negative implications.

The insights gained will help researchers and policy makers understand what has been offered in different parts of the world as a set of instruments and measures to estimate consumer vulnerability among children in relation to online marketing. Mostly, this study will focus on the poor understanding and knowledge of different generations of parents of the consequences of children's exposure on digital media advertising and essentially will open discussion for

* Corresponding Author E-Mail Address: ljupka.naumovska@gmail.com 
upscaling parent's role in regulating the children's unsupervised exposure on digital multimedia ads and content.

Children today are very comfortable using electronic technology, Internet, on line games and digital platforms (Lincényi, 2013). The dominant portion of the on line content is consumed via their parent's devices. This raises the complex question of whether and how Internet advertising can be regulated and how children can be protected from the negative implications (Eagle, De Bruin, 2001).

Children are affected by advertising at all ages, having different perceptive sensibility and thus vulnerability. Along with the rise of internet marketing, mobile marketing and multimedia omni-channel marketing communications, children exposure on on-line advertising has never been less supervised and at the same time more dangerous. Surprisingly, little is known of how media affect children differently at different ages, though it is commonly assumed, but yet, poorly proofed that younger children are more influenced and thus more sensitive due to the cognitive developments (Calvert, 2008). Assumptions of the negative impact of unsupervised internet advertising on children are categorized based on their cognitive development, and related to that, financial impact on domestic budget, co-related with increased children's influence over domestic costs (Naumovska, Efremov, Serafimovik, 2019).

Hence, this research aim is linked with two linked questions:

1. Who should assume responsibility for protection of children exposure on internet advertising?

2. What form(s) should the protection take?

However, these questions are not new. Dignam (1999, p. 27) argued that the -intellectual argument for banning ads to children is in itself infantilell. He observes that such bans will not prevent children from seeing ads in other media, will not prevent pester power which has been around long before advertising, nor will it prevent children from being swayed by other elements in the marketing mix - such as branding, point of sale and packaging (Schultz and Kitchen, 2000; Kitchen and Schultz, 2001; Kitchen, 2003). The common industry response at the beginning of these discussions were that if it is legal to sell a product, it should be legal to advertise (Jenkins, 1988).

Nevertheless, the pace of the digital marketing development has urged all involved parties to develop a more mindful approach toward these questions, taking into account the complexed ethical, psychological and financial implications of the unsupervised children exposure on digital advertising.

Parents play also an important role in mediating their children's behavior online especially for online advertising. Studies from different authors have found that parents' opportunity to regulate their children online is limited. Firstly, their intervention is rarely required when children are online and exposed to marketing practices. Secondly, it's important to understand that parents react base on their personal perception of risk and the level of perceived harm, which is related with their level of understanding and awareness of the negative implications.

\section{Children as Consumers in Digital Era at Different Ages}

Children today are comfortable using electronic technology, including the Internet, they are tech - savvy and natural with social media platforms (Calvert, 2008). However, knowing that children are not able to recognize media content from intentional advertising, raises the complex question of whether and how Internet advertising can be regulated and how children can be protected (Eagle, De Bruin, 2001).

Namely, a good number of empirical studies of the effects of advertising on children were examined by different researchers in accordance to the age of the children. According these findings, in general, it is clearly argued that all age groups of children are affected by advertising, both because different persuasion processes operate at different ages and because, 
presumably as a consequence, each age group is targeted by age-specific forms of advertising by the industry (Eagle at al. 2006).

Most reviews (Bandyopadhyay, Kindra and Sharp 2001, Hastings et al 2003, Calvert, 2008) conclude that before four or five years old, children regard advertising as simply amusement, that between four and seven, they begin to be able to distinguish advertising from organic media content, and starting to understand the intention to persuade by the age of eight, and that after eleven or twelve they can articulate a critical understanding of advertising and of the intentions of the advertisers.

These two factors - child's ability to distinguish advertisements from programs and, the cognitive skill to recognize the persuasive and commercial intent of advertising - are seen as crucial in all approaches (Kunkel and Wilcox 2001) for developing a further and deeper understanding of this major issue and thus, calling out regulations and active measures.

In addition to that, Roedder (1981) designed and tested a developmental model proposing three stages of advertising literacy related with children 's age group:

a) Limited: children under 8 years of age have zero knowledge for judging the intentions of advertisers.

b) Cued: children between age 8 and 12 years have the knowledge to counter argue advertising claims, but do not use this knowledge spontaneously.

c) Strategic: children with age over 12 years have both the knowledge and are able to use this strategic advertising literacy.

According empirical research, it seems clear that between seven or eight and eleven or twelve lies a delicate understanding in which children vary in the cognitive perception of advertising messages. Hence, they experience difficulties distinguishing advertising from other contents of the media, and they tend to accept the claims that advertisers project as reality (Buijzen and Valkenburg 2003a, 2003b).

By the time they are teenagers, children are already skeptical of advertising messages, more selective, and more distrustful of the claims made in advertisements (Calvert, 2008).

\section{The Psychological and Financial Effects of Advertising on Children}

The negative implications of children 's exposure to on line advertising can be categorized in: financial and psychological. Marketing to children is on the rise especially via digital media. Nowadays, children and members of Generation $\mathrm{Z}$ is tech savvy and their exposure and use of media devices is increasing their awareness and need for products and services that are advertised. Certain messaging based of fiction, fantasy and other abstract forms of communication via digital media can be seen harmful for younger consumers, twisting their perception and rational perception (Naumovska, Efremov, and Serafimovik, 2019a).

Dobrow (2002) asserts that considerable effort goes into planting the seeds of brand loyalty with this group. Hunter (2002) points out that children influence as much as $80 \%$ of a family 's food budget. In today's modern lifestyles, dominated by technological devices and digital media, children are greatly exposed to ads and messages that are fostering their eagerness, even creating anxiety for the advertised products and services. This aspect is even more urgent to consider, taking into account that children are exposed to digital media unattended and most of the time conditioned by their parents who are expecting certain behavior from them. (Naumovska, Efremov, and Serafimovik, 2019b).

Hence, when the rise in obesity, anxiety for products and other form of psychological implications and influence over domestic budgets are considered together with children 's vulnerability in terms of limited emotional and cognitive capacity to make fully rational decisions (Calvert, 2008), urges advertisers, researchers and institutions to give children special protection from marketing on line communications. The proposed regulations address schools, media literacy, advertising legislations and parents. Taking into account that the first three so 
far have been poorly performed, we set a new research frame work for more intensive accent on parental role, along with their knowledge and understanding of the current situation, possible consequence and impact.

\section{Ethics and Regulations of Children's Media Market}

According Kowalik and Danik (2018), the international companies rank highly the use of social media, and "communication with customers", necessary for explaining the use and attributes of products, but also for gathering insights. In the context of globally connected world and unregulated on line media market, this rises a set of issues.

A ban on advertising to children is unlikely to provide an overall solution - or help promote a general framework for decreasing the negative implications because in times of multi-channel communications, children are exposed to advertisements in all sorts of media. Recognition of the responsibility in protecting children is already acknowledged and should be allocated to several parties: parents, schools, advertisers and institutions (Eagle, De Bruin, 2001).

The identification of children as a particularly vulnerable group with regard to the purchase or use of digital content and intrusive online advertising has been made a key pillar of the consumer policy of both the European Commission (Europe Economics, 2011) and the European Parliament (European Parliament, 2012). The European Commission is working to ensure that all children across the EU/EEA enjoy an equally high level of protection, both regarding authorized and safe offers as well as illegal offers that are accessible in an inherently cross-border context. In particular, the Report from the Directorate-General for Justice and Consumers conduct on behalf on Produced by Consumers, Health, Agriculture and Food Executive Agency elaborate the effectiveness of the existing consumer protection measures provided by the Member States and/or by the industry, especially within the framework of the Unfair Commercial Practices Directive (2005/29/EC -UCPD), and the Audiovisual Media Services Directive (2010/13/EU - AVMSD).

A number of self-regulatory initiatives exist that have been put forward by the industry, but the effectiveness of self-regulatory measures especially in terms of protecting children from unfair commercial practices has been questioned by various authors. Paek et al. (2014) have argued that self-regulatory initiatives are affected by inconsistencies in the definitions of nutrition quality and the inclusion of allegedly "healthy lifestyle" messages in media placements. Their report shows that about $87 \%$ of food online advertising do not include age limit specifications, $71 \%$ include ad breaks and about half include healthy lifestyle information. Similarly, Nairn \& Hang (2012) have indicated that measures to mediate the effects of online advertising, such as labelling of commercial as advertisements or voluntary pledges by industry have been proven to be ineffective to protect children adequately in the UK. Given the inadequacies of selfregulatory measures to ensure a sufficient level of protection for children, Thomson (2011) has argued that health authorities should stop relying on industry self-regulation and should introduce stricter regulation on online advertising practices. Similarly, Potvin et al. (2012) have called for enhancing restrictions on internet marketing directed at children below 12 years of age, and criticize the absence of mandatory pre-clearance.

There are some specific regulations relating to advertising to children activated in different parts of the world related with separation of advertisements from editorials or programs. Advertising should not content violence or aggression, disturbing messages and should not encourage anti-social behavior and other related and protective elements for children. In Europe, there has been a renewed call for increased restrictions on advertising to children especially in European Union countries. For example, Greece has already imposed a total ban on toy advertising, Sweden bans all advertising targeted at children under the age of 12 and Ireland bans advertising within children's programs (Livingstone et al. 2011). From the other side online marketing involves a wide range of newly emerging marketing practices and 
techniques that make the application of existing legislation to such commercial practices particularly challenging. Different authors have research and question the ethics and regulation in the children's media market. Dahl et al. (2009) have stated that although regulators and the industry itself have attempted to restrict advertising to children through self-regulation and pledged to adhere to "responsible marketing" guidelines, advertisers appear to forget the promises as soon as they are operating online. Galbraith-Emami \& Lobstein (2013) have reviewed the impact of initiatives to restrict advertising of food and beverage products to children in EU countries and globally, and concluded that the pledges made by food and beverage manufacturers appear to have had only small or no impact so far.

However, there are much effort to be done in future in order to create healthy online environment for children. Four options may be put forward in relation to responsibility for protection of children from the negative impact of internet advertising: governmentsinstitutions; parents/guardians; and marketing industry.

\section{Parents Role in Regulation / Self-Regulation of Children's Exposure on Digital Media and Digital Ad Content}

As mention before parents play very important role in guidance and shaping behavior of their children regarding online advertising. They can help and protect their children from the exposure of content online in general. In the literature there are two approaches that are elaborated. The first one is related to the behavioral patterns or styles of the parents and the other is connected to the perceived lever of risk/harmfulness from the online advertising. Beside this there are several dimensions which can influence parental concerns. In the European commission study Justice and Consumers ${ }^{1}$ (2016), there are classified as: education, age of children, social status, and country.

From a theoretical background parental socialization may play important role in parental perceptions of how the marketplace interacts with children (Carlson and Grossbart, 1988). According to Baumrind (1980) parental socialization is an adult-initiated process in which children are guided to develop habits and values that are parallel with their culture. From other side parents can influence the development of their children by serving as role models (Evans, N.J at al. 2013 A). European commission report Justice and Consumers (2016) declare the parents' risk perception has also important role in detecting and regulation of children's exposure on digital media and digital ad content. In this report risk perception is operationalized in terms of measuring the perceived harm of a number of online hazards and their perception of the likelihood of the harm to occur. This approach in theory is widely accepted and is represent with risk score, the higher perceived risk from the parents the risk score is higher. According to Baumrind (1971, 1991), Evans N.J at all. (2013 B) there are four main types of parental behavioral patterns or styles: indulgent, neglecting, authoritarian and authoritative.

The first one, indulgent, style of parent's behavior tend to be more permissive than restrictive and warm rather than cold when interacting with their children (Walsh, Laczniak, and Carlson 1998 A). Furthermore, indulgent parents provide their child with adult rights but not adult responsibilities (Baumrind 1978). Neglecting parents are more detached from their children. Parents who are classified as neglecting have been shown to have little influence in the socialization process, which may lead their children to be influenced by outside consumer socialization agents such as peer groups, teachers, and media, including various forms of advertising (Walsh, Laczniak, and Carlson 1998 B). The third style is authoritarian and parents

\footnotetext{
${ }^{1}$ European Commission (2016), Study on the impact of marketing through social media, online games and mobile applications on children's behavior, [online]Produced by Consumers, Health, Agriculture and Food Executive Agency (Chafea) on behalf of Directorate-General for Justice and Consumers Directorate E — Consumers Unit E.1 (Consumer Markets), Available on: https://op.europa.eu/en/publication-detail/-/publication/1e978da4-9ab711e6-868c-01aa75ed71a1/language-en/format-PDF/source-113918684
} 
with this style attempts to shape, control, and evaluate the behavior and attitudes of the child in accordance with a set standard (Baumrind 1968, p. 890). Children of authoritarian parents are expected to obey without questioning their authority (Crosby and Grossbart 1984; Walsh, Laczniak, and Carlson 1998 C). Parents with authoritative style attempt to direct the child's activities in a rational, issue-oriented manner. They encourage verbal give-and-take and share with the child the reasoning behind their policies (Baumrind 1971). In comparison with authoritarian parents, authoritative parents typically work to balance their child's rights and responsibilities. They are warmer than authoritarians, encourage self-expression, but also expect children to act in a mature manner while adhering to family rules (Baumrind 1968; Gardner 1982; Walsh, Laczniak, and Carlson 1998 D). Research on parental attitudes of children's advertising has revealed links between one's parenting style and parental perceptions of the advertising in question (Evans at all., 2013; Bakir and Vitell 2010; Carlson, Laczniak, and Muehling 1994; Crosby and Grossbart 1984). Authoritarian and authoritative parents typically hold more negative attitudes toward

children's toy-based and food-based advertising compared to both indulgent and neglecting parents (Carlson, Laczniak, and Muehling 1994; Crosby and Grossbart 1984; Grossbart and Crosby 1984). According to Evans N.J. (2013) and his research, this same pattern of attitudinal differences among parenting styles remains for topics like regulation of children's television as well.

The role of the parents as a self-regulatory instrument is very important. Many researches indicate parents are willing to play the role of protector and educator to their children for online activities (Eagle, Bulmer, and de Bruin 2003). Form other side in order to educate their children the parents need to have sufficient online media literacy skills (Eagle 2007; Eagle, Bulmer, and de Bruin 2003). The European commission study "The impact of marketing through social media, online games and mobile applications on children's behavior" (2016) shows that parents believed there is high possibility of online hazards. The most harmful was perceived the Hazards related to violence online, also hazards related to marketing practices were considered slightly less harmful, but considerably more likely to occur. Moreover, digital identity theft is perceived by the parents very high, also different forms of online advertisements (about unhealthy lifestyles and foods) were ranked considerably high. EC study Justice and Consumers (2016) also show that parents believed that they could control their children's activity on social media. Moreover, friends, parents or even teachers might also have a profile in the same network, and they could also contribute to controlling their children's activities. Many parents reported educating their children of being cautious regarding what they post and warning them that whatever they post stay on the Internet forever was helpful. Also, stricter regulations for business and more education for children are considered as very effective measures. On the contrary, training sessions for parents and contact points or help lines were considered the least effective (EC report, 2016).

\section{Discussion and Conclusion}

The purpose illuminates the importance and the urgency of the regulation of children exposer on digital ad content and social media, and second the role of the parents as a regulator of their exposure. According literature review, essentially, the regulation of advertising to children must not be a result of ad hoc decision- making but rather the result of well- researched and informed policy debate, taking into account all parts of the world. Additionally, analysis within a principal- agent framework (where the principal is the government or a regulatory body and the agent is the regulated firm or industry) could help illuminate the way toward determining an optimal regulation. On the other side we should not underestimate the importance and the role of the parents as a regularity mechanism. From the previous research, we can see that certain parental style differ on how they perceive and understand the online exposure of their 
children and that influence their role in the process on regulation children exposure on online advertising. In addition to that, digital literacy of the parents it is important milestone in the proses positioning the parents in a role of as a self-regulation mechanism of children exposure. At last, all research before were conducted in economically developed parts of the world, mainly in U.S. and EU countries that limits the global perspective of this matter and potentially limits the regulations.

In order to inform the debate and future policy and global market direction, the following research program is underway by the authors of this paper:

a) Studies of parental preferences on the mode of advertising regulation are in progress. Results will be compared with similar studies undertaken in other countries and regions of the world.

b) Education and awareness rise of parents for the children 's media exposure negative implication and increase in on line media literacy.

c) A pilot study of primary school aged children, broken down into several age cohorts, will also be undertaken to investigate children's actual abilities to:

- distinguish between program and advertising, and

- level of understanding the commercial intention of advertisements, and In addition, children's perceptions regarding healthy versus unhealthy dietary practice will also be investigated.

e) Setting the Western Balkan non-EU countries in a cross - national context, taking into account that the dominant research of this topic has been done in U.S. and European Union countries.

\section{References}

Bakir, Aysen, and Scott J. Vitell (2010). The Ethics of Food Advertising Targeted Toward Children: Parental Viewpoint. Journal of Business Ethics, 91, 299-311.

Bandyopadhyay, S., Kindra, G. \& Sharp, L. (2001). Is television advertising good for children.? Areas of concern and policy implications. International Journal of Advertising, 20(1), pp. $89-116$

Baumrind, Diana (1968). Effects of Authoritarian Parental Control on Child Behavior. Child Development, 37, 887-907.

Baumrind, Diana (1971). Current Patterns of Parental Authority. Developmental Psychology Monograph, 4 (January), 1-103.

Baumrind, Diana (1978). Parental Disciplinary Patterns and Social Competence in Children. Youth and Society, 9, 238-76.

Baumrind, Diana (1980). New Directions in Socialization Research. American Psychologist, 5 (July), 639-52.

Baumrind, Diana (1991). Parenting Styles and Adolescent Development. in The Encyclopedia on Adolescence, Richard Learner, Anne C. Peterson, and James Brooks-Gunn, eds., New York: Garland, 746-58

Buijzen, M., and Valkenburg, P. M. (2003a). The effects of television advertising on materialism, parent- child conflict, and unhappiness: A review of research. Journal of Applied Developmental Psychology, 24(4), 437-456.

Buijzen, M., and Valkenburg, P. M. (2003b). The unintended effects of television advertising - A parent- child survey. Communication Research, 30(5), 483-503.

Calvert, Sarah. (2008). Children as Consumers: Advertising and Marketing. The Future of Children 18 (1): 205-234. 
Carlson, Les, and Sanford Grossbart (1988). Parental Style and the Consumer Socialization of Children. Journal of Consumer Research, 15 (1), 77-94.

Crosby Lawrence A., and Sanford L. Grossbart (1984). Parental Style Segments and Concern about Children's Food Advertising. Current Issues and Research in Advertising, 7 (1), 4363.

Dahl, S., Eagle, L. \& Báez, C. (2009). Analyzing advergames: active diversions or actually deception. An exploratory study of online advergames content. Young Consumers, 10(1), 46-59.

Dignam, C. (1999). Ethics will be key in battling EU-led children's ad ban. Marketing, 22 April 1999 , p. 27.

Eagle, L. and De Bruin, A. (2001). Advertising restrictions: Protection of the young and the vulnerable?. International Journal of Advertising and Marketing to Children, 2 (4). pp. 259271. ISSN 1747-3616

Eagle, L., Bulmer, S., De Bruin, A. and Kitchen, P. (2006). Adver- tising and children: issues and policy options. Journal of Promotion Management, 11 (2 \& 3). pp. 175-194. ISSN 10496491

Eagle, Lynne (2007). Commercial Literacy: What Does It Do, to Whom-And Does It Matter?. Journal of Advertising, 26 (2), 101-10.

Eagle, Lynne, Sandy Bulmer, and Anne de Bruin (2003). Marketing Communications Implications of Children's New Electronic Media Use: A Survey of Parental Opinions and Perceptions. Journal of Marketing Communications, 9 (3), 129-46.

European Commission (2016). Study on the impact of marketing through social media, online games and mobile applications on children's behavior, Produced by Consumers, Health, Agriculture and Food Executive Agency (Chafea) on behalf of Directorate-General for Justice and Consumers Directorate E - Consumers Unit E.1 (Consumer Markets), [online] Available on: https://op.europa.eu/en/publication-detail/-/publication/1e978da4-9ab711e6-868c-01aa75ed71a1/language-en/format-PDF/source-113918684

Evans, N. J., Carlson, L., \& Grubbs Hoy, M. (2013). Coddling Our Kids: Can Parenting Style Affect Attitudes Toward Advergames? Journal of Advertising, 42(2-3), 228-240.

Galbraith-Emami, S. \& Lobstein, T. (2013). The impact of initiatives to limit the advertising of food and beverage products to children: a systematic review. Obesity Reviews: An Official Journal of the International Association for the Study of Obesity, 14(12), 960-74.

Dobrow, Larry (2002, February 4). How old is enough? Advertising Age, 73(5), 4. Donohue, T. R. (1975). Effects of commercials on black children, Journal of Advertising Research, 15(6), 41-47.

Hastings G, Stead M, McDermott L, Forsyth A, MacKintosh AM, Rayner M, Godfrey C, Caraher M, Angus K (2003). Available: http://tna.europarchive.org2/0110116113217/ and http:/www.food.gov.uk/multimedia/pdfs/foodpromotiontochildren1.pdf

Hunter, Beatrice T. (2002, March). Marketing foods to kids: Using fun to sell, Consumers' Research 85(3), 13-19.

Jenkins, J. (1988). Tobacco advertising and children: Some Canadian findings, International Journal of Advertising, 7(4), 357-367.

Kunkel, D., and Wilcox, B., (2001). Children and media policy. In Singer, D.G. and Singer, J. L. (Ed.), Handbook of Children and the Media (pp. 589-604). Thousand Oaks, CA.: Sage. 
Kitchen, P. J., ed. (2003). The Future of Marketing: Critical $21^{\text {st }}$ Century Perspectives. Basingstoke, UK: Palgrave Macmillan.

Kitchen, P. J., and Schultz, D. E. (2001). Raising the Corporate Umbrella: Corporate Communications in the $21^{\text {st }}$ Century. Basingstoke, UK: Palgrave Macmillan.

Kowalik, I. and Danik, L. (2019). Marketing activity of international new ventures application of the EMICO framework. Journal of Business \& Industrial Marketing, Vol. 34 No. 4, pp. 779-791. https://doi.org/10.1108/JBIM-02-2018-0079

Laczniak, Russell N., Darrel D. Muehling, and Les Carlson (1995). Mothers' Attitudes toward 900-Number Advertising Directed at Children. Journal of Public Policy and Marketing, 14 (1), 108-16

Livingstone, S., Haddon, L. \& Görzig, A. (Ed.) (2012). Children, risk and safety on the Internet. Research and policy challenges in comparative perspective. Bristol, UK: The Policy Press

Livingstone, S., Haddon, L., Görzig, A., \& Ólafsson, K. (2011). Risks and safety on the internet: The perspective of European children. Full findings, produced under the EUKidsOnline II project.

Lynne Eagle, Sandy Bulmer, Anne de Bruin \& Philip J. Kitchen (2005). Advertising and Children. Journal of Promotion Management, 11:2-3, 175-194, DOI: 10.1300/J057v11n02_12

Marcel Lincényi (2013). Application of media education in lifelong learning. In: Digitalne medijske tehnologije i društveno-obrazovne promene 3. - Novi Sad: Faculty of Philosophy, 2013. - ISBN 978-86-6065-203-6. - s.191-198, CD ROM.

Nairn, A. \& Hang H. (2012). Advergames: “It's not an advert - it says play!". A review of research. London: Family and Parenting Institute.

Naumovska Lj, Gordana Serafimovic, and Ljupco Efremov (2019). Exposure and Use of Mobile Media Devices by Children: Challenges and Implications. UTMS Journal of Economics 10 (1): 125-134.

Paek, H. J., Quilliam, E. T., Kim, S., Weatherspoon, L. J., Rifon, N. J. \& Lee, M. (2014). Characteristics of food advergames that reach children and the nutrient quality of the foods they advertise. Internet Research, 24(1), 63-81.

Potvin, K. M., Dubois, L. \& Wanless, A. (2012). A nutritional comparison of foods and beverages marketed to children in two advertising policy environments. Obesity (Silver Spring, Md.), 20(9), 1829-37.

Roedder, D. L. (1981). Age difference in children's responses to television advertising: an information processing approach. Journal of Consumer Research, 8, 144-153.

Thomson, D. M. (2011). The mixed health messages of Millsberry: a critical study of online child-targeted food advergaming. Health Communication, 26(4), 323-31.

Walsh, Anne D., Russell N. Laczniak, and Les Carlson (1998). Mothers' Preferences for Regulating Children's Television. Journal of Advertising, 27 (3), 24-36. 